\title{
CORRELATIONS BETWEEN HEALTH CARE FACILITIES AVAILABILITY AND ACCEPTANCE ON QUALITY OF LIFE IN PATIENTS WITH TYPE 2 DIABETES MELLITUS
}

\author{
Dian Handayani'), Noor Alis Setiyadi²), Anisa Catur Wijayanti²) \\ 1)Masters Program in Public Health, Universitas Sebelas Maret \\ 2)Public Health Department, Faculty of Health Sciences, \\ Muhammadiyah Surakarta University
}

\begin{abstract}
Background: Quality if life is based on both objective and subjective parameters. The subjective parameters include wellbeing, happiness, and personal acceptance, while objective parameters are related to the satisfaction of basic needs, such as availability and access to health care facilities. The purpose of this study was to investigate correlations between health care facilities availability and acceptance on quality of life in patients with type 2 diabetes mellitus.

Subjects and Method: A cross sectional study was carried out at General Hospital of Surakarta, Central Java from October to November 2019. A sample of 131 type 2 diabetes mellitus patients aged $\leq 65$ years was selected by purposive sampling. The dependent variable was quality of life. The independent variables were health facilities and patient acceptance. Quality of life was measured by Quality of Life Instrument for Indian Diabetes patients (QOLID). Other variables were masured by questionnaire. The data were analyzed by Chi square.

Results: Good health facilities $(\mathrm{OR}=3.28 ; 95 \% \mathrm{CI}=1.41$ to $7.60 ; \mathrm{p}=0.004)$ and patient acceptance $(\mathrm{OR}=4.02 ; 95 \% \mathrm{CI}=1.57$ to $10.30 ; \mathrm{p}=0.002)$ improved quality of life of type 2 diabetes mellitus patients.

Conclusion: Good health facilities and patient acceptance improve quality of life of type 2 diabetes mellitus patients.
\end{abstract}

Keywords: diabetes mellitus, quality of life, health facilities, patient acceptance

Correspondence:

Dian Handayani. Masters Program in Public Health, Universitas Sebelas Maret. Jl. Ir. Sutami 36A, Surakarta 57126, Central Java. Email: dianhan1812@gmail.com. Mobile: 085876686231 